\title{
Housing Discrimination as a Basis for Interdistrict School Desegregation Remedies
}

The Supreme Court's 1974 decision in Milliken v. Bradley ${ }^{1}$ erected formidable barriers to interdistrict school desegregation relief. The Court held that lower courts may not institute interdistrict remedies absent proof of official discrimination in all school districts included in such remedies. It is thus the exclusively white suburbs that are most immune to courtordered school desegregation. To the extent that residential segregation is effective, official educational segregation disappears and so does the basis for a court-ordered remedy.

This Note describes a means of overcoming the Milliken barriers-a means the courts have used thus far only in a tentative and partial fashion. Official housing discrimination should serve as a basis for metropolitan school desegregation remedies even if plaintiffs offer no proof of discrimination by school officials. ${ }^{2}$ Use of this approach requires surmounting an additional obstacle, apart from the Milliken barriers, that stands in the way of intradistrict as well as interdistrict relief. The "traditional conception of adjudication" requires a neat conjunction between violation and remedy. ${ }^{3}$ Yet the housing approach requires one state agency to remedy the violations of another. A school board might wonder why it should remedy the wrongs of an altogether separate state agency. ${ }^{4}$

Part I describes the limited extent to which courts have already used this rationale. Part II discusses the precedents and empirical evidence supporting the proposition that, where the segregative decisions of a state housing agency cause school segregation, courts should adopt a single-

1. 418 U.S. 717 (1974).

2. This Note focuses on housing violations, but actions by governmental agencies charged with other kinds of functions have also promoted residential segregation and could provide additional bases for interdistrict school relief. Decisions by zoning, land use, and highway officials have helped to cause residential segregation. See, e.g., Sloane, Milliken v. Bradley and Residential Segregation, in U.S. Comm'n on Civil Rights, Milliken r. Bradley: The Implications for Metropolitan DesegRegation, ConfERenCe Before the U.S. COMM'N ON Civil Rights 85-86 (1976); cases cited infra notes 14, 95. Much of this Note's analysis of housing violations applies to these decisions.

3. See Chayes, The Role of the Judge in Public Law Litigation, 89 HARv. L. Rev. 1281, 1298 (1976).

4. The force of the continued reluctance to disregard this disjunction was illustrated in the St. Louis school desegregation litigation. Citing undisputed evidence of discrimination by state housing officials along with voluntary migration and socioeconomic factors as the causes of residential segregation, the court exonerated the school officials, even though Missouri had been joined as a defendant. Liddell v. Board of Educ., 469 F. Supp. 1304, 1323-24, 1363-64 (E.D. Mo. 1979), rev'd sub nom. Adams v. United States, 620 F.2d 1277, 1291 (8th Cir.), cert. denied, 449 U.S. 826 (1980). 
sovereign assumption to prevent officials of that school district from escaping remedial measures. When such links are shown, recent decisions suggest that courts may properly presume that state action has also distorted the processes of local educational decisionmaking. Part III analyzes the problems of proving causation and discriminatory intent that arise in actual application of this "housing approach."

\section{The Present Status of Basing School Desegregation Remedies on Official Housing Discrimination}

Although no claims of housing discrimination were before the Court in Milliken, Justice Stewart asserted in a concurring opinion that housing or zoning discrimination could justify interdistrict school desegregation relief. ${ }^{5}$ This statement remains the only clear endorsement by a Supreme Court Justice of the housing approach to school desegregation.

Since 1974, federal courts in Wilmington and Indianapolis have partially based interdistrict school remedies on housing violations. In Wilmington, the court found that the municipal housing authority had jurisdiction to establish publicly assisted housing projects up to five miles beyond the city limits, but as of 1972 had located fewer than forty of two thousand units outside the city limits. ${ }^{6}$ This practice concentrated poor and minority families inside Wilmington. ${ }^{7}$ The court's finding that this practice intensified segregation in schools throughout the metropolitan area helped to justify a sweeping eleven-district remedy. ${ }^{\mathbf{B}}$

In Indianapolis, the municipal housing agency's area of operation similarly extended five miles beyond the city limits in all directions. ${ }^{9}$ All

5. Milliken v. Bradley, 418 U.S. 717,755 (1974) (Stewart, J., concurring):

This is not to say, however, that an interdistrict remedy of the sort approved by the Court of Appeals would not be proper, or even necessary, in other factual situations. Were it to be shown, for example, that state officials had contributed to the separation of the races by drawing or redrawing school district lines, . . . by transfer of school units between districts, . . . or by purposeful, racially discriminatory use of state housing or zoning laws, then a decree calling for transfer of pupils across district lines or for restructuring of district lines might well be appropriate.

Although housing violations were not before the Court in Milliken, the district court had found housing violations by state officials and had partially based its decision on such violations. Bradley $v$. Milliken, 338 F. Supp. 582, 586-87 (E.D. Mich. 1971). However, the court of appeals expressly did not base its partial affirmance on these findings of housing violations. 484 F.2d 215, 242 (6th Cir. 1973). The Supreme Court concluded that it had no questions concerning housing violations before it. 418 U.S. 717, 728 n.7 (1974).

6. Evans v. Buchanan, 393 F. Supp. 428, 435 (D. Del.) (Evans II) (three-judge court) (interdistrict remedy not barred by Milliken because interdistrict segregation in Evans significantly caused by state action), aff'd per curiam, 423 U.S. 963 (1975).

7. Id.

8. The court ordered the consolidation of 11 school districts. Id.

9. United States v. Board of School Comm'rs, 456 F. Supp. 183, 188-90 (S.D. Ind. 1978) (Indianapolis V), aff'd in part and vacaled in part, 637 F.2d 1101, 1109-10 (7th Cir.), cerl. denied, 449 Ü.S. 838 (1980). 
eleven public housing projects approved by the municipal and county housing agencies since 1964 were located within the inner-city school district, which was predominantly black. ${ }^{10}$ The determination that these housing decisions affected school enrollments throughout the metropolitan area formed part of the basis for a comprehensive metropolitan remedy. ${ }^{11}$

Successful intradistrict examples of the housing approach occurred in Kalamazoo, ${ }^{12}$ Coney Island, ${ }^{13}$ and other localities. ${ }^{14}$ In these cases, courts imposed school desegregation orders on single districts partly on the basis of findings of official housing discrimination. However, since the obstacles to interdistrict relief are much higher, these intradistrict cases have limited precedential force.

Despite the two interdistrict cases and the use of the housing approach in several intradistrict cases, the housing approach remains an uncertain strategy. The Court specifically reserved the question in Swann $v$. Charlotte-Mecklenburg Board of Education. ${ }^{15}$ Whenever faced with a lower court opinion addressing the housing approach, the Court has resolved the case without issuing an opinion. ${ }^{16}$ Moreover, Justice Stewart's endorsement of the approach in his concurring opinion in Milliken came in a single phrase at the end of a very long sentence. ${ }^{17}$ Though some believe that Justice Stewart's words might provide an independent basis

10. Most of these projects consisted of single-family apartment units, and of these, $98 \%$ of the occupants were blacks. United States v. Board of School Comm'rs, 637 F.2d at 1109.

11. Id.

12. See Oliver v. Kalamazoo Bd. of Educ., 368 F. Supp. 143 (W.D. Mich. 1973) (school desegregation order based on violations of school board and other state agencies), aff'd sub nom. Oliver v. Michigan State Bd. of Educ., 508 F.2d 178 (6th Cir. 1974), cert. denied, 421 U.S. 963 (1975).

13. See Hart v. Community School Bd., 383 F. Supp. 699 (E.D.N.Y.) (Coney Island school desegregation order based on violations of school board as well as state and federal housing bodies joined as defendants), appeal dismissed, 497 F.2d 1027 (2d Cir. 1974), aff'd, 512 F.2d 37 (2d Cir. 1975).

14. See Ybarra v. City of San Jose, 503 F.2d 1041 (9th Cir. 1974) (finding improper dismissal of suit by lower court where plaintiffs' case rested on "a legal principle so unsettled" as the claim that zoning and building permit policies might justify school desegregation relief); Reed v. Rhodes, $422 \mathrm{~F}$. Supp. 708 (N.D. Ohio 1976) (Reed I) (ordering desegregation based on violations by school board but stressing that school policies should be seen in context of segregated public housing), later proceeding, 581 F.2d 570 (6th Cir. 1978), aff'd in part, 607 F.2d 714 (6th Cir. 1979), cerl. denied, 445 U.S. 935 (1980). In Chicago, the recent approval of an intradistrict remedy specifically attributed the perpetuation of segregation in the city's schools to the continuing failure of housing authorities to counteract residential segregation. United States v. Board of Educ., 554 F. Supp. 912 , 913 n.2 (N.D. Ill. 1983) (approving consent decrec) ("[B]ecause racial patterns in a neighborhood school system obviously mirror racial housing patterns, the continuing delinquencies of the City of Chicago's administrations in not taking steps to arrest the growth, let alone change the pattern, of de facto segregation in housing were major contributors to the problem.").

15. In Swann v. Charlotte-Mecklenburg Bd. of Educ, 306 F. Supp. 1299, 1304 (W.D.N.C. 1969), aff'd in part and vacaled in part, 431 F.2d 138 (4th Cir. 1970), aff'd in part and vacated in part, 402 U.S. 1 (1971), the trial court found that school segregation resulted from myriad forms of state action: zoning, city planning, urban renewal, public housing siting, and restrictive covenants. The Supreme Court did not address these findings. 402 U.S. 1, 23 (1971).

16. See cases cited supra notes 6 (Wilmington), 9 (Indianapolis), 12 (Kalamazoo), 13 (Coney Island), 14 (Cleveland), and infra note 21 (St. Louis).

17. Milliken v. Bradley, 418 U.S. 717, 755 (1974) (Stewart, J., concurring). See supra note 5. 
for relief, ${ }^{18}$ others take the suggestion as merely an "offhand remark."10 No court has relied on the housing approach exclusively or even primarily. In cases in which housing violations have influenced the terms of a school desegregation remedy, courts have always found discrimination in education as well. ${ }^{20}$ The St. Louis litigation promised to provide a precedent for interdistrict relief heavily dependent on evidence of metropolitan area-wide housing discrimination, but the parties settled. ${ }^{21}$ The Supreme

18. See, e.g., Sloane, supra note 2 , at 81,84 (at least five Justices would probably uphold metropolitan relief on a showing that housing officials, not just school officials, were responsible for concentrating blacks in inner cities); W. Taylor, The Supreme Court and Urban Reality: A Tactical Analysis of Milliken v. Bradley, 21 WAyne L. Rev. 751, 768-69 (1975) (calling attention to potential importance of Justice Stewart's suggestion, sketching housing approach and stressing need for litigation to determine whether its promise is "real or illusory"); Note, Interdistrict Desegregation: The Remaining Options, 28 STAN. L. REv. 521, 544 (1975) (causal link between housing discrimination and school segregation not obvious but can be established).

19. U.S. Comm'N ON CIviL RIGHTS, supra note 2, at 29. See Amaker, Milliken v. Bradley: The Meaning of the Constitution in School Desegregation Cases, in id. at 11, 13 (Stewart's approach "refractory," even if one seizes upon his "advertence [sic] to the use of State housing or zoning laws by State authorities to maintain segregation as one means of demonstrating the need for a metropolitan remedy"). One survey of the status of interdistrict remedies dismisses Justice Stewart's proposed housing approach in three sentences, citing the difficulty in showing the discriminatory intent of state housing and zoning laws. See Note, Interdistrict Remedies for Segregated Schools, 79 Colum. L. REv. 1168, 1176 (1979). However, discriminatory intent reflected in the actions and policies of housing and zoning officials, as well as in the laws themselves, violates the equal protection clause. $C f$. Yick Wo v. Hopkins, 118 U.S. 356, 373-74 (1886) (neutral licensing law applied in discriminatory fashion violates equal protection clause).

20. The Wilmington and Indianapolis decisions, for example, rest more heavily on one of the two justifications for interdistrict relief that the Milliken majority allowed: the deliberate manipulation of school district lines by school officials to preserve segregation. Milliken v. Bradley, 418 U.S. 717, 745 (1974) ("Thus an interdistrict remedy might be in order where the racially discriminatory acts of one or more school districts caused racial segregation in an adjacent district, or where district lines have been deliberately drawn on the basis of race."); id. at 755 (Stewart, J., concurring). See United States v. Board of School Comm'rs, 456 F. Supp. 183, 187-88 (S.D. Ind. 1978) (Indianapolis V), aff'd in parl and vacated in part, 637 F.2d 1101, 1106-08 (7th Cir.) (affirming district court on intentionally segregatory manipulation of school district lines), cert. denied, 449 U.S. 838 (1980); Evans v. Buchanan, 393 F. Supp. 428, 445-46 (D. Del.) (three-judge court) (Evans II), aff'd per curiam, 423 U.S. 963 (1975). "Manipulation" may mean failure to change district boundaries as political boundaries change. For example, Indianapolis, Louisville and Kansas City have predominantly black inner city school districts whose boundaries have been prevented from expanding as the cities have grown. Kansas City now contains all or part of thirteen school districts. The inner city Kansas City Municipal School District was originally contiguous with the city limits but was prevented from expanding after the late 1950's and is now predominantly black while the other districts are predominantly white. M. Wise, D. Field \& S. Dougherty, Proposed Intervention in Black v. Missouri, Memorandum Submitted to R. Rheinstein, Chief, General Litigation Section, U.S. Dep't of Justice 37-38 (1980) (on file with Yale Law Journal). See Newburg Area Council v. Board of Educ, 510 F.2d 1358,1361 (6th Cir. 1974) (confinement of Louisville school district to inner city core allows 10,000 mostly white students living inside city to attend county schools), cert. denied, 421 U.S. 931 (1975).

21. The agreement to settle provided St. Louis County with the nation's first comprehensive, voluntarily enacted busing program between a large city and its suburbs. N.Y. Times, Feb. 23, 1983, at A1, col. 5 . All but one of the county's 23 school districts agreed to participate in a plan calling for busing 15,000 black students from the city to suburban schools. Id. The settlement grew out of prolonged litigation that had already resulted in a court-imposed intradistrict remedy within the city of St. Louis, based solely on the failure of school officials to desegregate after 1954. See Adams v. United States, 620 F.2d 1277, 1291-97 (8th Cir.), cert. denied, 449 U.S. 826 (1980). However, the court of appeals indicated that all governmental policies tending to promote segregation could be important in determining whether to order interdistrict relief. Adams v. United States, 620 F.2d at 1291, 1294 \& 
Court, meanwhile, continues to emphasize the limits on the equitable remedial powers of the lower courts necessitated by federalism and local self-determination. ${ }^{22}$

The courts have, in effect, experimented with the housing approach for nine years since Milliken. ${ }^{23}$ The attraction of basing claims on the violations of housing officials is not only that it can justify broad metropolitan relief, but also that it focuses the attention of the courts on the causes of residential segregation, which is the fundamental source of contemporary school segregation.

\section{School Segregation by Non-School Officials and the SINGLE-SOVEREIGN ASSUMPTION}

\section{A. Evasive Schemes and the Single-Sovereign Assumption}

At first sight, the housing approach seems inconsistent with Milliken. If purposeful racial discrimination by school officials in District X is insufficient under Milliken to justify court-ordered desegregation remedies in District $Y$, purposeful racial discrimination by state housing officials arguably also falls short of justifying remedies in District $Y$.

The Milliken bar to interdistrict relief, however, applies only where the segregative effects of the violations by District X's school officials are con-

n.27. Housing violations and other state actions promoting residential segregation were an important part of the plaintiffs' case in the proceedings considering the motion for interdistrict relief prior to the settlement agreement of February 22, 1983. See Brief for Defendant 7-11, Liddell v. Board of Educ,, No. 72-100-C(4) (E.D. Mo. 1982) (discussing addition of housing and land use authorities for interdistrict phase of litigation). The housing approach is a part of the plaintiffs' strategy in suits brought by the NAACP Legal Defense Fund in Kansas City, Missouri, and by the U.S. Department of Justice in Yonkers, New York. The Kansas City litigation has entered a new phase following court-ordered realignment of the parties and dismissal of Kansas defendants. School Dist. v. Missouri, 460 F. Supp. 421 (W.D. Mo. 1978) (rejecting defendants' motion for summary dismissal that claimed, inter alia, legal irsufficiency in plaintiffs' allegation that federal housing, highway and educational agencies caused school segregation), appeal dismissed, 592 F.2d 493 (8th Cir. 1979). This suit is being continued with new parties and a new name. See Black v. Missouri, 492 F. Supp. 848 (W.D. Mo. 1980).

22. See, e.g., Rizzo v. Goode, 423 U.S. 362, 379 (1976) ("[A]ppropriate consideration must be given to principles of federalism in determining the availability and scope of equitable relief."); Doran v. Salem Inn, Inc. 422 U.S. 922, 928 (1975) (efficient judicial administration subordinate to claims of federalism). But see City of Rome v. United States, 446 U.S. 156, 179 (1980) (principles of federalism that might otherwise limit congressional authority necessarily overridden by power to enforce Fourteenth Amendment); Fitzpatrick v. Bizer, 427 U.S. 445, 456 (1976) (same). Skepticism about the capacity of equitable remedies to effect meaningful social change reinforces these limits on equitable remedies. See, e.g., Delaware State Bd. of Educ. v. Evans, 446 U.S. 923, 925-27 (1980) (Rehnquist, J., dissenting from denial of certiorari) (arguing that white flight outside control of school authorities suggests futility of massive court-imposed integration); Cleveland Bd. of Educ. v. Reed, 445 U.S. 935, 938 (1980) (Rehnquist, J., dissenting from denial of certiorari) (equitable decrees cannot fashion an "Emerald City" where races and classes will live side by side).

23. The experiments are few but promising. As demographer Karl Taeuber recently remarked, "[T]he jurisprudential link between school segregation and housing segregation is still in the developing stages and may have profound legal effects on both school law and housing law." Taeuber, Housing, Schools, and Incremental Segregative Effects, 441 AnNals 157, 165 (1979). 
fined to District X. The Court in Milliken suggested an exception to the general bar when school officials outside District $Y$ cause segregation in District $Y .^{24}$ The availability of relief in District $Y$ is therefore not necessarily contingent upon a showing of discrimination by school officials in District $Y$. This exception arguably involves no disjunction between violation and remedy, since the violators and the appliers of the remedy are all agents of the education bureaucracy of the state government. Similarly, the Milliken exception countenances the housing approach, since the violators and the appliers of the remedy are all agents of the same state government. $^{25}$ Milliken itself thus provides some basis for the housing approach.

Although Justice Stewart did not cite them, there are cases supporting the housing approach..$^{26}$ As the federal courts became attuned to the sophisticated "evasive schemes" available to states bent on avoiding desegregation, the courts developed the argument that a disjunction between violation and remedy of the type involved in the housing approach is overcome by a showing that an arm of the state caused school segregation.

In Cooper v. Aaron, ${ }^{27}$ the Supreme Court rejected an effort to delay desegregation by the Little Rock School Board, which claimed that the governor and state legislature were obstructing peaceful implementation of

24. Milliken v. Bradley, 418 U.S. 717, 745 (1974); see supra note 20. For examples of interdistrict remedies based solely on the majority's two exceptions, see Morrilton School Dist. No. 32 v. United States, 606 F.2d 222, 228-29 (8th Cir. 1979) (two predominantly white school districts not directly implicated in establishment of predominantly black districts included in remedy because "the effects of the unconstitutional state action are felt in both districts"), cerl. denied, 444 U.S. 1050 and 444 U.S. 1071 (1980); United States v. Missouri, 388 F. Supp. 1058 (E.D. Mo.) (ordering remedy for three districts in St. Louis County where boundaries were drawn to preserve segregation), aff'd in part and ret'd in part, 515 F.2d 1365 (8th Cir.) (en banc), later opinion, 523 F.2d 885 (8th Cir.), cert. denied, 423 U.S. 951 (1975); Hoots v. Pennsylvania, 359 F. Supp. 807, 822 (W.D. Pa. 1973) (Hoots $I I$ ) (state and county education officials drew school district boundaries "based wholly or in part on" race of students involved), appeal dismissed, 495 F.2d 1095 (3d Cir.), cert. denied, 419 U.S. 884 (1974), remedy ordered, No. 71-538 (W.D. Pa. 1981) (Hoots VIII) (five-district consolidation and desegregation ordered), aff'd, 672 F.2d 1107 (3d Cir.) (Hoots IX), cerl. denied, 103 S. Ct. 55 and 103 S. Ct. 172 (1982). The Hools II court took note of the "pervasive" housing discrimination and residential segregation in the area but did not base its decision on findings of official housing violations. Hoots II, 359 F. Supp. at 816 (W.D. Pa. 1973).

Since 1974, federal and state courts have held interdistrict remedies proper in nine cases. Hoots VIII is the most recent. On the other eight, including two decisions that skirted Milliken by predicating relief on state constitutional grounds, see School Desegregation: Hearings on $H . J$. Res. 56 Before the Subcomm. on Citil and Constitutional Rights of the House Comm. on the Judiciary, 97th Cong., 1st Sess. 671 \& n.7 (1981) (report by C. Dale) [hereinafter cited as House Desegregation Hearings].

25. See infra p. 347.

26. The courts in the Wilmington and Indianapolis cases relied on Justice Stewart's phrasing to support their partial adoption of the housing approach. Evans v. Buchanan, 393 F. Supp. 428, 438 (D. Del.) (three-judge court) (Evans II), aff'd per curiam, 423 U.S. 963 (1975); United States v. Board of School Comm'rs, 419 F. Supp. 180, 182 (S.D. Ind. 1975) (Indianapolis IV), aff'd, 541 F.2d 1211, 1222-23 (7th Cir. 1976), vacated and remanded, 429 U.S. 1068 (1977). For similar reliance on Stewart's concurrence, see Ybarra v. City of San Jose, 503 F.2d 1041, 1043 (9th Cir. 1974).

27. 358 U.S. 1 (1958). 
court-ordered desegregation measures. ${ }^{28}$ The Court held that, for Fourteenth Amendment purposes, a local school board is an arm of the state, and that when an arm of the state stands accused of equal protection violations, the state itself stands accused. A state, in other words, cannot defend itself by pointing to its own obstructions.

Federal courts have struck down a number of other efforts to perpetuate unconstitutional segregation by some fragmentation, reallocation, or divestment of state governmental authority. A state may not, for example, close public schools, lease them to educational cooperatives, and then fund the schools when they reopen as nominally private schools run by the existing school boards. ${ }^{28}$ With equal decisiveness, the courts have struck down more oblique strategies for funneling public money for tuition payments to students attending nominally private segregated schools. ${ }^{30}$ The Fourteenth Amendment speaks to the state, and state officials cannot escape the force of the equal protection clause simply by splintering or rearranging authority. ${ }^{31}$

The "evasive schemes" cases indicate that action by an arm of the state that causes or perpetuates segregation in schools activates a singlesovereign assumption. The single-sovereign assumption applies regardless of how much independence the state constitution or statutes give to the agency involved. The assumption may apply even to nominally private agencies. ${ }^{32}$ The same notion - that a state does not shield itself from the

28. Id. at $15-17$.

29. See Hall v. St. Helena Parish School Bd., 197 F. Supp. 649 (E.D. La. 1961) (three-judge court), aff'd per curiam, 368 U.S. 515 (1962).

30. See Griffin v. County School Bd., 377 U.S. 218 (1964) (upholding power of federal courts to reopen public schools where state of Virginia closed them and created tuition aid program for students attending private schools); Poindexter v. Louisiana Fin. Assistance Comm'n, 275 F. Supp. 833 (E.D. La. 1967) (enjoining as segregative enforcement of statute setting up state commission to make tuition grants), aff'd per curiain, 389 U.S. 571 (1968); Lee v. Macon County Bd. of Educ., 267 F. Supp. 458 (M.D. Ala.) (three-judge court) (basing desegregation decree on various unconstitutional state actions tending to promote segregation, including tuition grants, transportation, and survey officials' recommendations on school sites), aff'd per curiain sub nom. Wallace v. United States, 389 U.S. 215 (1967); Bush v. Orleans Parish School Bd., 190 F. Supp. 861 (E.D. La. 1960) (enjoining state legislature's scheme to block access of local board to bank deposits where aim was to frustrate desegregation), aff'd per curiam sub nom. City of New Orleans v. Bush, 366 U.S. 212 (1961).

31. The Cooper Court held:

The command of the Fourteenth Amendment is that no 'State' shall deny to any person within its jurisdiction the equal protection of the laws. . . The constitutional provision, therefore, must mean that no agency of the State, or of the officers or agents by whom its powers are exerted, shall deny to any person within its jurisdiction the equal protection of the laws. Whoever, by virtue of public position under a State government, . . . denies or takes away the equal protection of the laws, violates the constitutional inhibition; and as he acts in the name and for the State, and is clothed with the State's power, his act is that of the State.'

Cooper v. Aaron, 358 U.S. 1, 16-17 (1958) (quoting Ex parte Virginia, 100 U.S. 339, 347 (1880)); see Hall v. St. Helena Parish School Bd., 197 F. Supp. 649, 658 (E.D. La. 1961) (three-judge court) (state may not "evade its constitutional responsibility by carve-outs of small units"), aff'd per curiam, 368 U.S. 515 (1962).

32. Examples include nominally private schools and educational cooperatives. See cases cited 
Fourteenth Amendment by splitting authority into a multiplicity of departments-forms the jurisprudential foundation of the housing approach. $^{33}$

This foundation differs from the theories of agency and vicarious liability rejected by the Court in Milliken. ${ }^{34}$ In Milliken, the Court found violations only by the Detroit school board ${ }^{35}$ Apart from those violations, the state had not created the dual school system. Plaintiffs relied on theories of agency and vicarious liability to assert that state school officials were responsible for the wrongdoing of the Detroit board. Such a rationale, however, would justify not merely the metropolitan remedy sought by the plaintiffs, but a statewide one. The Court therefore rejected these theories as violating the rule of equity that a remedy must not exceed the extent of the violation..$^{36}$

By contrast, the housing approach is limited in two ways. It does not justify expansion of the remedy beyond the geographical area of operation of the housing authority or other governmental entity found guilty of constitutional violations. Further, the scope of the remedy is limited to the extent to which official housing discrimination demonstrably caused school segregation. Consequently, the housing approach is consistent with the agency principle that seeks to prevent local agents of the state from escaping participation in remedies for their own wrongdoing. ${ }^{37}$

supra notes 29-30.

33. See United States v. Board of School Comm'rs, 573 F.2d 400, 410 (7th Gir. 1978) ("The commands of the Fourteenth Amendment are directed at the state and cannot be avoided by a fragmentation of responsibility among various agents."), cert. denied, 439 U.S. 824 (1978) and 449 U.S. 838 (1980); Oliver v. Kalamazoo Bd. of Educ., 368 F. Supp. 143, 183 (W.D. Mich. 1973) (state "should not be allowed to escape constitutional responsibility by fractionalizing its jurisdiction through many agencies"), aff'd sub nom. Oliver v. Michigan State Bd. of Educ., 508 F.2d 178 (Gth Cir. 1974), cert. denied, 421 U.S. 963 (1975); United States v. Missouri, 363 F. Supp. 739, 748 (E.D. Mo. 1973) (state "cannot escape responsibility for the racial discrimination disclosed in this case or the obligation to correct the effects of such discrimination by neatly compartmentalizing the authority and responsibility of its various instrumentalities"), supp. opinion, 388 F. Supp. 1058 (E.D. Mo.), aff'd in part and rev'd in part, 515 F.2d 1365 (8th Cir.) (en banc), later opinion, 523 F.2d 885 (8th Cir.), cert. denied, 423 U.S. 951 (1975).

34. See Milliken v. Bradley, 418 U.S. 717, 738, 744-46 (1974) (rejecting agency arguments); see also Reed v. Rhodes, 422 F. Supp. 708, 793 (N.D. Ohio 1976) (Reed I) (governor not liable though plaintiffs claimed that his appointment powers to state real estate and banking boards should make him vicariously liable for actions of boards' members), later proceeding, 581 F.2d 570 (6th Cir. 1977), aff'd in parl, 607 F.2d 914 (6th Cir. 1979), cert. denied, 445 U.S. 935 (1980).

35. Sep supra note 5.

36. Milliken v. Bradley, 418 U.S. 717, 738, 744-46 (1974); see infra p. 355.

37. There are parallel applications of the single-sovereign assumption where the courts have held that the Constitution protects other kinds of rights from state action. See, e.g., Gaston County v. United States, 395 U.S. 285, 293, 296-97 (1969) (striking down otherwise valid and neutrally administered literacy test for voter registration to remedy wrongs of dual school system). The Court has also evoked the single-sovereign assumption to protect the constitutional right against double jeopardy. Waller v. Florida, 397 U.S. 387, 394 (1970) (barring prosecution in a state court after prosecution in municipal court because both are arms of same sovereign); Grafton v. United States, 206 U.S. 333, 354-55 (1907) (prosecution in federal court bars subsequent prosecution in court of United States territory because both are arms of same sovereign); of. Griggs v. Duke Power Co., 401 U.S. 424, 


\section{B. The Rationale for the Single-Sovereign Assumption is Fragmentation of Authority, Not Danger of a Conspiracy}

A possible objection to finding support for the housing approach in the evasive schemes cases would be that housing-approach cases do not allege deliberate conspiracies or collusion between housing and school officials. Court opinions in two of the intradistrict housing approach cases stressed that school officials were aware of housing decisions and policies. ${ }^{38}$ However, the evasive schemes cases are devoid of language suggesting that courts must find active cooperation between governmental entities before the entities will be treated as arms of the same sovereign. Indeed, in Cooper v. Aaron, the Court conceded the "good faith" efforts of the Little Rock School Board to integrate the city's schools. ${ }^{39}$

\section{The Requirement of a Causal Connection}

Plaintiffs relying on the housing approach must show a causal connection between the unconstitutional actions of state housing officials and the

430-31 (1971) (interpreting Title VII to require private corporation to adapt employment tests to compensate for effects of dual school system).

38. See Reed I, 422 F. Supp. at 790; Oliver v. Kalamazoo Bd. of Educ., 368 F. Supp. at 184-85. It might be possible to show collusion in some cases were it deemed necessary. In the Cleveland intradistrict case, for example, the court found not only that school officials agreed to erect schools to serve all-black housing projects, but also that assurances of the availability of adequate classroom space were prerequisites to federal funding of the projects. See Reed I, 422 F. Supp. at 789.

39. See Cooper v. Aaron, 358 U.S. 1, 14-15 (1958); id. at 21 (Frankfurter, J., concurring). The Kalamazoo decision suggests a much looser version of this purely hypothetical collusion requirement for desegregation relief-a showing that school officials knew of the discriminatory actions of housing officials, or (looser still) should have known. The Kalamazoo district court apparently assumed wrongly that one or the other of these two conditions had to be shown. The opinion stresses the Kalamazoo School Board's "intimate knowledge" of residential areas in the city and "extensive knowledge" of the way public agencies, as well as private groups functioned. Oliver v. Kalamazoo Bd. of Educ., 368 F. Supp. at 184-85. Consequently, the court held the school board liable for failure to counteract school segregation resulting from official housing decisions. Id. at 185.

Similarly, in the Cleveland case, the district court used the evidence of official housing discrimination partly to demonstrate an intent to discriminate on the part of school officials. The court could not lend credence to the school board's claim that its neighborhood school policy was racially neutral, because many schools were built to serve housing projects that were racially identifiable from their inception. Reed I, 422 F. Supp. at 790.

This use of housing discrimination evidence to shed light on the discriminatory intent of school officials is an alternate justification for school desegregation remedies independent of the housing approach, because it does not depend on activation of the single-sovereign assumption. If there were a requirement that school officials know of the discriminatory impact of housing policies, it probably would not be a significant obstacle for the housing approach inasmuch as it is hard to imagine a school board without the level of public awareness the court found in the Kalamazoo case. But such a requirement need not be fulfilled. The single-sovereign theory does not exist, or does not only exist, as an antidote to the threat of conscious cooperation by agents of the state. It follows necessarily from the language of the equal protection clause (" $N$ ]or shall any State . . . deny to any person within its jurisdiction the equal protection of the laws," U.S. CoNST. amend. XIV, $\$ 1$ (emphasis added)) and serves as an antidote to the institutionalized compartmentalization of authority inherent in state governments which often makes it difficult to pin the blame for some kinds of Fourteenth Amendment violations on any one agency. 
racial composition of the schools in the district where desegregation remedies are sought. Unless this requirement is met, defendants could easily distinguish the evasive schemes cases, in which the causal connection is always obvious. More fundamentally, satisfaction of the requirement is dictated by the Supreme Court's doctrine that equitable remedies may not exceed what is necessary to undo the effects of the violation. ${ }^{40} \mathrm{~A}$ school remedy for housing violations is therefore permissible only to the extent that the violation caused school segregation.

Many court opinions reveal a general assumption or unverified hypothesis that the causes of modern urban segregation are primarily nongovernmental. A finding of effective state action depends on how the finder of fact weighs the various causes of segregation, but such opinions assume a weighing that leaves little or no room for state action as a cause. On the Supreme Court, several Justices take the view that voluntary migration, economic circumstances, and perhaps differing rates of birth among the races have caused school segregation. ${ }^{11}$ Some lower court judges share these beliefs. ${ }^{12}$ This attitude toward the causes of contemporary urban segregation inhibits imposition of judicial remedies because the courts cannot issue injunctions to counteract demographic and economic change.

40. See infra p. 355.

41. For Justice Powell's views, see Estes v. Metropolitan Branches of Dallas NAACP, 444 U.S. 437, 445 (1980) (per curiam) (Powell, J., dissenting from dismissal of certiorari) ("In large cities, the principal cause of segregation in the schools is residential segregation, which results largely from demographic and economic conditions over which school authorities have no control."); Columbus Bd. of Educ. v. Penick, 443 U.S. 449, 480 (1979) (Powell, J., dissenting) (residential segregation "caused by social, economic and demographic forces for which no school board is responsible"); Austin Indep. School Dist. v. United States, 429 U.S. 990, 994 (1976) (Powell, J., concurring) (principal cause of racial and ethnic imbalance in urban public schools across nation is imbalance in residential patterns "typically beyond the control of school authorities"). For Justice Stewart's views, see Milliken v. Bradley, 418 U.S. 717, 756 n.2 (1974) (Stewart, J., concurring). Justice Stewart also joined Justice Powell's dissent in Estes. Justice Rehnquist joined Justice Powell's opinions in the Estes and Austin cases. See also Pasadena Bd. of Educ. v. Spangler, 427 U.S. 424, 435-36 (1976) (Rehnquist, J.) (resegregation caused by "quite normal pattern of human migration" not attributable to school board). Chief Justice Burger joined Justice Powell's concurrence in Austin. See also Swann v. CharlotteMecklenburg Bd. of Educ., 402 U.S. 1, 26, 31-32 (1971) (Burger, C.J.) (warning that few communities remain demographically stable and that, absent evidence that state officials have deliberately fixed or altered demographic patterns to affect racial composition of schools, further intervention of courts is unwarranted). For an carly post-Milliken discussion of Supreme Court views of urban segregation, see W. Taylor, supra note 18 , at $760-63$.

42. See, e.g., Bradley v. School Bd., 462 F.2d 1058, 1066 (4th Cir. 1972) ("We think that the root causes of the concentration of blacks in the inner cities of America are simply not known ...."); Liddell v. Board of Educ., 469 F. Supp. 1304, 1363 (E.D. Mo. 1979) ("The overwhelming, inexorable cause of the racial imbalance in the schools is the aggregate movement of individuals in response to cconomic forces."); Evans v. Buchanan, 393 F. Supp. 428, 449 (D. Del.) (Evans II) (three-judge court) (Layton, J., dissenting) ("no definitive explanation for the huge tide of black immigration into the nation's cities, and the white flight therefrom, in the past two decades"), aff'd per curiain, 423 U.S. 963 (1975). 
No one questions that residential segregation causes school segregation. Social scientists and the Court also agree to the converse proposition: School segregation promotes residential segregation. ${ }^{43}$ In recognizing the reciprocal influence of different forms of segregation, however, courts have tended to close discussion before they address the real issue: the extent to which state action, rather than private discrimination or demographic and economic factors, causes residential segregation.

Social science research has for years offered conclusions at odds with the non-responsibility of government hypothesis, ${ }^{44}$ and the evidence continues to mount. Private volition becomes a less plausible explanation for segregated neighborhoods as both blacks and whites become more favorably disposed towards integrated neighborhoods. ${ }^{45}$ Moreover, a broad na-

43. School segregation contributes to residential segregation in three important ways. First, families deciding where to live often take the racial composition of local schools into account. Second, public housing authorities often will not site units until school officials have agreed to provide educational facilities. Third, private developers of segregated housing often promise to dedicate land to a school board in a new subdivision that agrees to erect a school on the land. For expressions of the reciprocity theory by the Court and by social scientists, see Columbus Bd. of Educ. v. Penick, 443 U.S. 449, 465 n.13 (1979); Keyes v. School Dist. No. 1, 413 U.S. 189, 202 (1973); Swann v. Charlottc-Mecklenburg Bd. of Educ., 402 U.S. 1, 20-21 (1971); Orfield, School Segregation and Residential Segregation, in W. Stephan \& J. Feagin, School Desegregation 227, 234-35 (1980); Taeuber, supra note 23, at 157 ("reciprocal interplay between housing and school segregation").

44. See, e.g., K. Taeuber \& A. Taeuber, Negroes in Cities 78-95 (1965) (demonstrating with 1960 census data that socioeconomic factors are weak predictors of residential segregation); Farley, Residential Segregation and Its Implications for School Integration, LAw \& CoNTEMP. ProBs., Winter 1975, at 164, 174-77, 190 (similar conclusions based on 1970 census data).

45. On the attitudes of blacks, see Farley, Schuman, Bianchi, Colasanto \& Hatchett, "Chocolate City, Vanilla Suburbs": Will the Trends Toward Racially Separate Communities Continue?, 7 Soc. ScI. Research 319, 321 (1978) (proportion of Detroit blacks preferring to live in racially mixed neighborhoods rose from 56\% in 1968 to $83 \%$ in 1976); Taeuber, Housing and School Segregation in Indianapolis, INTEGRATEDuchtion, Jan.-Apr. 1979, at 14, 15-16 (author's "own studies" show "overwhelming choice" of blacks is integrated neighborhoods). To be sure, some blacks and whites still favor segregation, but these attitudes are themselves partly a product of official policies which, for example, taught by direct example that school segregation is legitimate and desirable. Id. at 17. Blacks who have had integrated educations, for example, are more likely to try to live in integrated neighborhoods than blacks with segregated educations. Id. Blacks do not see moving from the ghettos to the suburbs as deserting the black community. Farley, Bianchi \& Colasanto, Barriers to the Racial Integration of Neighborhoods: The Detroit Case, 441 Annals 97, 111 (1979).

On the feelings of whites, see Orficld, supra note 43, at $231 \mathrm{n} .1$ (13\% of whites in 1978 said they would move if black family moved next door, compared to $35 \%$ in 1967 and $45 \%$ in 1963); Farley, Bianchi \& Colasanto, supra, at 105 (only 7\% of Detroit whites would try to move upon arrival of first black family in fifteen-house neighborhood and 23\% with three of fifteen houses occupied by blacks); D. Taylor, Housing, Neighborhoods and Race Relations: Recent Survey Evidence, 441 ANNALs 26, 33 (1979) (in national sample, only about $5 \%$ of whites object to new black neighbor of equal income and education, a far more tolerant attitude than in 1965 poll); D. Taylor, Sheatsley \& Greeley, Attitudes Toward Racial Integration, 238 ScI. AM. 42, 43 (1978) (white attitudes toward residential and educational integration became dramatically more favorable according to nationwide surveys in $1963,1970,1972$, and 1976). Whites leave areas only when they fear their neighborhoods and schools will become overwhelmingly black. See C. Rossel., Assessing THE UNINTENDEd IMPACTS of PUBlic Policy: School Desegregation and Resegregation (1978) (substantial white flight occurs only in school districts more than $35 \%$ black); D. Taylor, supra, at 32,34 (white reaction to neighborhood integration depends primarily on the amount of integration they believe will eventually occur). 
tional consensus has developed in support of integrated education. ${ }^{46}$ Social scientists also agree that only interdistrict school integration over a wide metropolitan area will effectively reduce the incentive for white flight and stabilize residential integration. ${ }^{\mathbf{7 7}}$

The theory that blacks do not move to the suburbs because they cannot afford to has also been discredited. Blacks have made great economic strides since World War II, but they have been unable to move out of the ghettos in great numbers. Blacks generally have greater difficulty than whites in finding suburban housing. ${ }^{48}$ Where black movement into the suburbs has occurred, it has usually taken the form either of tentacle-like

Recent research has also confirmed that white flight from neighborhoods and schools significantly increases during at least the first year of an intradistrict school desegregation remedy. See Armor, White Flight and the Future of School Desegregation, in W. Stephan \& J. FeaGin, supra note 43, at 188 (pointing out that two early critics of "white flight thesis," Farley and Rossell, have modified their views and that there is now less disagreement on the fact of white flight when desegregation occurs). For acknowledgments of the existence of white flight from scholars with a range of attitudes toward busing, see House Desegregation Hearings, supra note 24, at 160 (statement of G. Orfield), 206 (statement of D. Armor), 217 (statement of C. Rossell); Court-Ordered School Busing: Hearings on S. 528, S. 1005, S. 1147, S. 1647, S. 1743, and S. 1760 Before the Subcomm. on Separation of Pouers of the Senate Comm. on the Judiciary, 97th Cong., 1st Sess. 193 (1981) (statement of J. Ross) [hereinafter cited as Senate School Busing Hearings]. According to Armor, studies have shown that intradistrict busing plans are responsible for between $30 \%$ and $70 \%$ of the loss of white students in Boston, Denver, Detroit, Los Angeles, Memphis, San Francisco, Dallas, Oklahoma City, Chatanooga, Birmingham, Dayton, Omaha, and Seattle. House Desegregation Hearings, supra note 24, at 214 (statement of D. Armor). But see G. ORfield, Must WE Bus? 97-101 (1978) (citing Berkeley, Calif., and Evanston, Ill., as specific examples of towns where intradistrict desegregation has encouraged and stabilized residential integration); Taeuber, supra note 23, at 166 (citing Milwaukee as similar example).

46. G. Orfield, supra note 45, at 108-09; D. Taylor, Sheatsley \& Greeley, supra note 45, at 43 (graph) (more than $80 \%$ of whites in nationwide surveys in 1972 and 1976 favored integrated education).

47. There is a growing consensus that intradistrict busing causes substantial immediate white flight. See supra note 45 . There seems to be equal agreement among social scientists that a metropolitan remedy drastically reduces or eliminates white flight. For expressions of this latter view from scholars with varied attitudes toward busing, see House Desegregation Hearings, supra note 24, at 160-61 (statement of G. Orfield), 194, 198-203 (statement of D. Pearce) (demonstrating empirically that broad metropolitan remedies remove the incentives for whites to move), 216 (statement of $D$. Armor), 220 (statement of C. Rossell); Senate School Busing Hearings, supra note 46, at 232 (statement of R. Farley). For a specific study of the impact of an interdistrict remedy on white flight, see J. Raffel, The Politics of School Desegregation: The Metropoltran Remedy in DelaWARE 185-87 (1980). Compare Raffel, The Voters Grade the Metropolitan Desegregation Plan in Delaurare, Integrateducation, Jan.-Apr. 1980, at 64, 68-69 (white enrollments in New Castle County, site of Wilmington suit, dropped only from $73.9 \%$ to $71 \%$ in first two years of interdistrict desegregation, 1978-80, and this was part of a continual decline from $81.2 \%$ in 1971) with OFFICE ON School. Monitoring \& Community Relations, EnRollment Decline and School DesegREgation in Cleveland: AN ANal.ysis of TRENDS aNd Causes 23 (1982) (showing substantial white flight in first two years of intradistrict remedy, though attributing no more than $36 \%$ of this flight to the remedy) and C. Rossell, A School Desegregation Plan for East Baton Rouge Parish, study submitted to U.S. Dept. of Justice 7 (1983) (on file with Yale Law Journal) (showing drop in white enrollments in elementary and secondary schools from 9640 to 4599 in first three years of intradistrict remedy and attributing $48 \%$ of this flight to desegregation).

48. See Farley, supra note 44, at 190; U.S. Comm'N on Civil Rights, Twenty Years AFter Brown: EqUAL OPPORTUNITY IN Housing 13 (1975); Roof, The Shifting Basis of American Race Relations, 441 ANNALS 1, 5-6 (1979). 
extensions of the inner city ghetto (e.g., East Cleveland) or of a new minighetto (e.g., Pontiac, Michigan). ${ }^{49}$ On average, blacks still make less money than whites. ${ }^{50}$ However, as recent work on census data shows, most suburbs are closed to blacks no matter what their incomes. ${ }^{51}$ Nor are blacks misinformed about the availability of suburban housing. ${ }^{52}$ The view that government is significantly responsible for residential segregation in American cities is therefore not a tentative hypothesis among social scientists, nor the subject of significant controversy. ${ }^{\mathrm{BS}}$

It is possible to be overly pessimistic about the impotence of this research to affect judicial outcomes. ${ }^{54}$ Unlike most arguments in legal briefs, social science evidence works gradually over time to change judges' perceptions about social reality. ${ }^{\mathrm{Bb}}$ Though no Justice has renounced previous assumptions that state action has little to do with residential segregation, ${ }^{\text {s6 }}$

49. See Pettigrew, A Sociological View of the Post-Milliken Era, in U.S. CoMm'N on CrviL RIGHTS, supra note 2, at 53, 60; U.S. Comm'N ON Civil Rights, supra note 48, at 131, 134; Roof, supra note 48 , at 7 .

50. See U.S. Bureau of the Census, Money Income of Households, Families, and Persons in the United States: 1980, Current Population Reports, Series P-60, No. 132, Table 2 (median household income in current dollars rose between 1967 and 1980 from $\$ 7,449$ to $\$ 18,684$ for whites, and from $\$ 4,325$ to $\$ 10,764$ for blacks).

51. Farley, Bianchi \& Colasanto, supra note 45 , at 99 (Detroit study). On the basis of 1970 census data, urban demographers demonstrate that if income were the only factor, more than twice as many blacks would live in New York's suburbs as actually do, more than four times as many in Detroit's and Cleveland's, nearly six times as many in Chicago's and ten times as many in Baltimore's. Farley, supra note 44, at 175-76 (fig. 4) (actual proportion of blacks in suburbs versus proportion expected on basis of 1970 income for 15 large cities); Taeuber, supra note 45, at 14-15 (reporting various statistical examinations showing that economic factors are not sufficient or cven primary explanation for racial residential segregation). But see Wolf, Northern School Desegregation and Residential Choice, 1977 Sup. CT. REv. 73-74 (estimates of importance of economic factors vary).

52. See Farley, Bianchi \& Colasanto, supra note 45 , at 111.

53. To dramatize their consensus, thirty-seven prominent social scientists signed a "Social Science Statement" on school and residential segregation published in 1980. Among the chief assertions of this unusual manifesto is a forceful statement of governmental responsibility for residential segregation. See Orfield, supra note 43, at 233-34 ("Thus will past discriminatory practices of the FHA and other housing agencies continue for decades to come to exert an influence on the racial structure of the nation's metropolitan areas."); see also G. ORFIELD, supra note 45, at 408-09; U.S. CoMM'N ON Crvil Rrghts, supra note 48, at 167-68 (criticizing federal government's role in causing residential segregation). The authors originally drafted the statement in support of the Columbus and Dayton desegregation suits before the Supreme Court, apparently to counteract the tendency of courts to discount social science studies on the grounds of inconclusiveness or disagreement among scholars.

54. E.g., Yudof, School Desegregation, Legal Realism, Reasoned Elaboration, and Social Science Research in the Supreme Court, Law \& Contemp. Probs., Autumn 1978, at 57, 62, 70, 89 (courts disinclined to give much credence to social science research because of "vagaries of the research," "disputations over methodology," and "policy conclusions"); see also City of Mobile v. Bolden, 446 U.S. 55, $75 \mathrm{n} .22$ (1980) (plurality opinion) (denigrating social science evidence that an ethnic minority lacks political influence as "gauzy sociological considerations").

55. See W. Taylor, The Supreme Court and Recent School Desegregation Cases: The Role of Social Science in a Period of Judicial Retrenchment, LAw \& ConTEMP. PROBS., Autumn 1978, at 37, 39; see also Dworkin, Social Sciences and Constitutional Rights, 6 J.L. \& Educ. 3, 4-9 (1977) (social science interpretations-such as interpretation that school desegregation stigmatizes blacks-as distinct from causal judgments, have influenced many desegregation decisions).

56. See supra p. 349. 
it may be cause for some hope that no Justice has espoused the nonresponsibility of government hypothesis in print since $1980 .{ }^{57}$

\section{Local Control of Education}

The Milliken Court stressed the damage such court orders purportedly do to local control and autonomy in educational decisionmaking. ${ }^{58}$ In Hills v. Gautreaux, ${ }^{58}$ the Court held that Milliken allows courts to order remedies beyond the municipal boundaries where the constitutional violation occurred. Milliken only limits the power of the courts to interfere with the operation of local governmental entities not implicated in unconstitutional conduct. ${ }^{60}$ In Hills, Milliken posed no obstacle to a metropolitan housing remedy because housing had not been the responsibility of local governmental entities. ${ }^{61}$ In devising school desegregation remedies, however, the courts must take into account the interests of local authorities in managing their own affairs. ${ }^{62}$ In fact, the Hills Court explained that even clear evidence of constitutional violations by state officials might not justify interdistrict school desegregation relief where the state educational structure vests substantial independence in local school districts. ${ }^{63}$ Even if metropolitan remedies are reconcilable with local control, ${ }^{84}$ concern for

57. The non-responsibility of government hypothesis does not, for example, appear in either of the two dissents from denials of certiorari authored by Justice Rehnquist in 1980 . Delaware State Bd. of Educ. v. Evans, 446 U.S. 923 (1980) (Evans VIII) (Rehnquist, J., dissenting from denial of certiorari); Cleveland Bd. of Educ. v. Reed, 445 U.S. 935 (1980) (Rehnquist, J., dissenting from denial of certiorari). But of. supra note 41.

58. 418 U.S. 717, 741-43 (1974).

59. 425 U.S. 284 (1976). Hills was a suit against the United States Department of Housing and Urban Development (HUD) for its role in assisting the Chicago Housing Authority's racially discriminatory housing program. Id. at 289.

60. Hills v. Gautreaux, 425 U.S. at 298 (metropolitan area-wide housing remedy consistent with Milliken because it does not compromise authority or interfere with operation of local governmental entities).

61. Id. at 300-06.

62. See Milliken v. Bradley, 433 U.S. 267, 280-81 (1977) (Milliken II); Milliken v. Bradley, 418 U.S. 717, 741-43 (1974) (Milliken I); Hills v. Gautreaux, 425 U.S. at 294-96.

63. Hills v. Gautreaux, 425 U.S. at $296,298 \mathrm{nn} .13-14$.

64. Sep Gittel, The Political Implications of Milliken v. Bradley, in U.S. Comm'N on CiviL Rights, supra note 2, at 41 (considerable room remains for decentralized decisionmaking within the context of state-funded metropolitan desegregation); U.S. CoMm'N ON CIVIL RIGHTS, STATEMENT on Metropolitan School Desegregation 49 (1977) (apart from ensuring that students are assigned to schools in a nondiscriminatory way, there would be no need to centralize authority over other aspects of educational process); W. Taylor, Metropolitan Remedies for Public School Discrimination, 10 URB. REV. 188-89 (1978) (decisions about hiring faculty and administrators, about curriculum and budget can remain highly localized and coexist with interdistrict student assignment). .

On the specific example of the Wilmington remedy, compare Delaware State Bd. of Educ. v. Evans, 446 U.S. 923, 923 (1980) (Evans VIII) (Rehnquist, J., dissenting from denial of certiorari) (Wilmington remedy labeled "more Draconian than any ever approved by this Court") with J. RAFFEL, supra note 47 , at 195, 210-14 (stressing relative success of Wilmington remedy because of broad, active community participation in planning and implementing desegregative measures) and Raffel, supra note 47, at 64,71 (popular dissatisfaction with public education results as much from county's failure to solve administrative problems as from busing and student reassignment). 
local control will restrict both the scope and the type of relief that the courts will grant. ${ }^{65}$

Until 1982, the Supreme Court's formulations of the local control issue essentially created a presumption in favor of the status quo and functioned as restraints on the exercise of judicial remedial power to affect public education. ${ }^{66}$ However, in Washington v. Seattle School District No. $1^{\text {6z }}$ and Crawford $v$. Board of Education, ${ }^{68}$ the Court may have signaled a shift in emphasis away from protection of local decisionmaking from outside interference and toward protection of the integrity of the processes by which communities exercise self-determination in educational decisionmaking. The Court seemed eager to reinforce representative and participatory principles in school district governance, rather than simply to preserve the existing distribution of authority. ${ }^{6 \theta}$ This concern with the processes of local control has been present in Court decisions for a long time, ${ }^{70}$ but not so visibly as now. Concern for process and concern for the substance of local control do not always dictate the same remedial approach. Protection of processes represents a restraint on judicial power but does not automatically justify the status quo.

Milliken provides an illustration of the difference. There the Court offered local control as a reason for rejecting interdistrict relief. ${ }^{71}$ It is difficult to justify that decision as reinforcing representative principles in local decisionmaking processes. School officials were not blamed for residential segregation, but the Detroit metropolitan area was nevertheless divided into nearly all-black and nearly all-white school districts. ${ }^{72}$ The pervasive segregation in the schools was in no sense a product of democratic processes. As in the nation as a whole, the majority of the population of

65. One court has cited concern for local control as a reason for favoring busing or student transfers over redrawing district lines. See United States v. Board of School Comm'rs, 637 F.2d 1101, 1114 (7th Cir.) (remedy most closely tailored to violation would be to expand boundaries of inner city school district to city lines, but this "would have been far more intrusive into local political processes"), cert. denied, 449 U.S. 838 (1980). It may not be constitutional for courts to order interstate school desegregation remedies in metropolitan areas that straddle state lines, especially where two states had interstate compacts in the domain of public education. But cf. School Dist. v. Missouri, 460 F. Supp. 421, 431, 435 (W.D. Mo. 1978) (claim in school segregation case that Kansas City, Kansas, defendants had maintained climate of discrimination forcing blacks to resettle in Kansas City, Missouri, held insufficient to invoke Missouri long-arm statute), appeal dismissed, 592 F.2d 493 (8th Cir. 1979).

66. See cases cited supra note 62; Dayton Bd. of Educ. v. Brinkman, 433 U.S. 406, 410 (1977) (Dajton I); San Antonio Indep. School Dist. v. Rodriguez, 411 U.S. 1 (1973).

67. 102 S. Ct. 3187 (1982).

68. 102 S. Ct. 3211 (1982).

69. Washington v. Seattle School Dist. No. 1, 102 S. Ct. 3187, 3195-204 (1982).

70. Milliken v. Bradley, 418 U.S. 717, 742 (1974).

71. See supra p. 353.

72. See Milliken v. Bradley, 418 U.S. 717, 799-800 (1974) (Marshall, J., dissenting) (more than $70 \%$ of Detroit schools had proportion of white or black students exceeding $90 \%$ ). 
the Detroit area has not opposed integration. ${ }^{23}$ The creation of uniracial electorates is, at best, an anomaly in representative processes. ${ }^{74}$

Where a significant causal connection can be established between state housing decisions and school segregation, a court's concern for the integrity of local processes should create a presumption that favors the housing approach rather than the status quo. Such a showing indicates that state action has skewed the racial composition of school district electorates. In this respect, the corrupting impact of housing discrimination on local decisionmaking processes is analogous to that of racial gerrymandering. ${ }^{75}$ Moreover, such a showing means that the decision about whether to have integrated schools has been partially or entirely removed to another, more distant level of government, the housing bureaucracy, which is not directly responsive to local or popular will. In this respect, the effect of housing discrimination resembles that of the unconstitutional Seattle anti-busing law.

The Court's concern for local processes suggests that when state action distorts the racial composition of school board electorates, redrawing district lines as a remedial measure has advantages over busing or student transfers. Such a remedy would counteract segregation not only in schools, but in elections of school boards. Ronald Dworkin believes that desegregation decisions have often been intended not simply as a cure for past violations but as prophylactics to counteract the high probability of racism in certain governmental decisionmaking processes. ${ }^{36}$ Redrawing school district lines to remedy housing violations would both integrate the schools and correct the systematic corruption of school board elections.

\section{Application of the Housing Approach}

\section{A. The Extent of the Violation}

Swann and its progeny indicate that the scope of the remedy in a school desegregation case may not exceed the nature and extent of the violation. ${ }^{77}$

73. See Farley, Bianchi \& Colasanto, supra note 45, at 105 (1976 study of whites in Detroit area showed only $6 \%$ would feel "very uncomfortable" with one black per 13 whites in their neighborhood, only $15 \%$ with three blacks per 11 whites, and only $29 \%$ with five blacks per nine whites).

74. Like the Milliken majority opinion, Justice Powell's dissent in Seattle expressed the substantive side of the Court's concern for local control. Washington v. Seattle School Dist. No. 1, 102 S. Ct. 3187, 3204-11 (1982) (Powell, J., dissenting). Justice Powell insisted several times that the case concerned structural and substantive authority, and he charged the majority with intruding on the rights of states to structure the decisionmaking operations of their local units. Id. at 3205, 3207, 3208, 3209, 3210 n.14, 3211 \& n.17 (Powell, J., dissenting).

75. See Gomillion v. Lightfoot, 364 U.S. 339 (1960) (striking down a redrawing of city lines that disenfranchised a disproportionately large number of blacks for purposes of municipal elections).

76. See Dworkin, supra note 55, at 11.

77. See, e.g., Milliken v. Bradley, 433 U.S. 267, 280-81 (1977) (Milliken II); Milliken v. Bradlcy, 418 U.S. 717, 738, 744-46 (1974) (Milliken I); Swann v. Charlotte-Mecklenburg Bd. of Educ., 
Courts should therefore tailor a housing-approach remedy to the scale of school desegregation demonstrably caused by housing violations. This limitation on equitable remedies has two polar interpretations. At one extreme is the view of Justice Rehnquist that a court would have to find that residential patterns were attributable "solely or principally" to state action. ${ }^{78}$ At the other extreme is the standard that courts have applied to direct state assistance to segregated schools: "any aid" at all is unconstitutional if discriminatory intent of school officials is shown. ${ }^{79}$ Justice Stewart recommended an intermediate standard: The court should find a violation when a state imposes, fosters or encourages residential segregation "in any significant measure." ${ }^{\text {"so }}$ Lower courts have applied this last standard in housing-approach cases. ${ }^{81}$ Its obvious imprecision leaves considerable discretion to the trial courts.

In the late 1970's, however, it appeared that the "incremental segregative effect" requirement of Dayton Board of Education v. Brinkman (Dayton $I)^{\mathbf{8 2}}$ might severely restrict this discretion. This requirement calls for untangling many complicated and interwoven strands of cause and effect, sorting out those state actions with identifiable segregative impact, and devising a remedy to cure only the segregation caused by state actions. ${ }^{83}$ Rigid application of this rule could effectively bar relief through the housing approach, for housing discrimination is inherently an indirect cause of school segregation, and many significant forms of official housing discrimination are as diffuse and intangible as they are pervasive.

However, it now appears unlikely for two reasons that Dayton I will constitute a significant obstacle to the housing approach. First, the Su-

402 U.S. 1, 16 (1971).

78. See Delaware State Bd. of Educ. v. Evans, 446 U.S. 923, 927-28 (1980) (Ez'ans VIII) (Rehnquist, $J$, dissenting from denial of certiorari).

79. Poindexter v. Louisiana Fin. Assistance Comm'n, 275 F. Supp. 833, 854 (E.D. La. 1967) ("[D]ecisions on the constitutionality of state involvement in private discrimination do not turn on whether the state aid adds up to 51 percent or adds up to only 49 percent of the support of the segregated institution"), aff'd per curiam, 389 U.S. 571 (1968). The district court in Poindexter cited other decisions that found constitutional violations despite the attenuation or obliqueness of state causation of private discrimination, 275 F. Supp. at 854-55. See Mulkey v. Reitman, 64 Cal. 2d 529, 413 P.2d 825, 50 Cal. Rptr. 881 (1966) (state constitutional amendment overturned because repeal of earlier fair housing legislation by state created atmosphere conducive to racial discrimination), aff' $d$, 387 U.S. 369 (1967); Anderson v. Martin, 375 U.S. 399 (1964) (requiring racial identification of candidates on ballot furthers private discrimination); Burton v. Wilmington Parking Auth., 365 U.S. 715 (1961) (state action requirement fulfilled by state ownership of premises leased to restaurant that discriminated).

80. Milliken v. Bradley, 418 U.S. 717, 756 n.2 (1974) (Stewart, J., concurring); see Norwood v. Harrison, 413 U.S. 455, 465-66 (1973) (textbook loans by state to students attending private segregated schools unconstitutional because of "significant tendency" to facilitate and support private discrimination).

81. See United States v. Board of School Comm'rs, 637 F.2d 1101, 1109 (7th Cir.) (state action must have had a significant rather than a de minimis effect), cert. denied, 449 U.S. 838 (1980).

82. 433 U.S. 406 (1977).

83. See Dayton I, 433 U.S. at 420. 
preme Court apparently does not intend the test to apply to cases involving de jure segregation. ${ }^{84}$ Second, even for cases of de facto segregation, the courts may not apply the Dayton I test with such rigor as to thwart the housing approach. In the Indianapolis case, the court stated that some constitutional violations found by the court had effects that "cannot be demonstrated statistically" but concluded that "it is reasonable to infer a moderate indirect effect." ${ }^{\text {"8s }}$ The court also demonstrated that the incremental effect standard could be applied to housing violations. ${ }^{86}$

\section{B. Showing Causation}

In the Wilmington and Indianapolis cases, the housing evidence mainly involved public housing siting decisions. Such evidence permits the courts to say with precision how many black families were concentrated in the ghetto and would have been integrated into other residential areas had public housing been more evenly dispersed. Until at least the 1960's, public housing agencies tended to concentrate housing projects in large American cities ${ }^{87}$ and maintain separate waiting lists by race to perpetuate seg-

84. Id. at $410 \mathrm{n.4}$ (noting that racially segregated schools had been illegal in Ohio since 1888). Dayton $I$ left open the possibility that, in de jure cases, meeting the standards of Swann and Keyes would suffice because a de jure school system is presumed to be segregated throughout, not merely incrementally. This possibility was tested when the Wilmington district court issued its remedial plans. That court stated it was "fully cognizant" that the plans were formulated without "exacting consideration" of whether they would return schools to the position they would have been in but for the violations of housing and school officials. Evans v. Buchanan, 447 F. Supp. 982, 1009 (D. Del.) (Evans VIII), aff'd, 582 F.2d 750 (3d Cir. 1978), cert. denied, 446 U.S. 923 (1980). On review, the court of appeals conceded that no Dayton $I$ inquiry had been undertaken by the district court but excused this omission on the grounds that Wilmington had previously been subject to de jure segregation. Evans VIII, 582 F.2d at 763-64 (case distinguished from Dayton I on grounds that Delaware law mandated school segregation until 1954). Justice Rehnquist protested that the Court had never exempted cases of de jure segregation from the Dayton I inquiry. 446 U.S. at 925 (Rehnquist, J., dissenting from denial of certiorari). In the Indianapolis suit, the Seventh Circuit similarly concluded that no Dayton I inquiry was needed because school segregation had been sanctioned by a state law preventing expansion of the inner city school district as the city grew. United States v. Board of School Comm'rs, 637 F.2d 1101, 1113 (7th Gir.) (incremental effect test applies if only isolated examples of discrimination are established, as in Denver, Columbus and Dayton, where discrimination often affected only one school district at a time), cert. denied, 449 U.S. 838 (1980).

85. United States v. Board of School Comm'rs, 506 F. Supp. 657, 670 (S.D. Ind. 1979), aff'd in part and vacaled in part, 637 F.2d 1101 (7th Cir.), cert. denied, 449 U.S. 838 (1980).

86. Before deciding that the incremental segregative effect standard was irrelevant, the Seventh Circuit had remanded the case for application of the Daylon $I$ inquiry. United States v. Board of School Comm'rs, 573 F.2d. 400, 414 (7th Cir.) (urging district court "explicitly" to consider Dayton I test). On remand, the district court provided an example of the sensible application of the incremental effect standard to housing violations in a housing-approach case. Having determined the precise number of black pupils $(4,958)$ concentrated in the inner city school district by public housing siting decisions, the court ordered that a roughly $60 \%$ greater number of students $(8,000$ to 8,500$)$ participate in the interdistrict transfer remedy, reasoning that there tends to be some movement of blacks into private housing around public housing sites. United States v. Board of School Comm'rs, $456 \mathrm{~F}$. Supp. 183, 190 (S.D. Ind. 1978) (Indianapolis V), later opinion, 506 F. Supp. 657, 670 (S.D. Ind. 1979), aff'd in part and vacated in part, 637 F.2d 1101 (7th Cir.), cert. denied, 449 U.S. 838 (1980).

87. ABA Advisory Comm'n on Housing and Urban Growth, Housing for All. Under 
regation..$^{88}$ The evaporation of public funding for housing has made it impossible to correct this situation with housing remedies. ${ }^{88}$

Courts can also rely on evidence that does not permit such easy quantification. The pre-Milliken Kalamazoo decision rested heavily on the lingering effects of state-enforced restrictive covenants. ${ }^{80}$ Use of this kind of evidence requires plaintiffs to provide a historical perspective on the development of racial concentration, in order to demonstrate the link between current patterns of segregation and former official practices. The same is true of evidence that federal mortgage and loan guarantee programs administered by the Federal Housing Administration (FHA) and Veterans Administration (VA) promoted residential segregation. Several courts have taken note of this phenomenon..$^{91}$ For years, the FHA and VA refused to provide financing for blacks who wanted to move out of the ghetto. ${ }^{92}$ The notorious FHA Underwriters Manual made perpetuation of segregation a matter of ethics for real estate brokers. ${ }^{93}$ State governments have fre-

LAw 21-23 (1978).

88. See $i d$. at 22 n.102; U.S. COMM'N ON CiviL Rights, supra note 48, at 46-47; see also United States v. Housing Auth., 504 F. Supp. 716, 728, 733 (S.D. Ala. 1980) (striking down municipal citizenship requirement for public housing where city had no black residents since 1940's).

89. Although the 1960 's were a turning point, racial concentration through public housing decisions or official foot-dragging on residential integration is still significant. See U.S. CoMM'N ON CIvIL RIGHTS, HOME OWNERSHIP FOR LOWER INCOME FAMILIES 89 (1971) (segregation perpetuated through Section 235 program); Orfield, The Role of Local and Federal Governments in Neighborhood Segregation, Integrateducation, May-Aug. 1979, at 48, 52 (overall impact of St. Louis housing programs probably inhibits integrated education).

90. Oliver v. Kalamazoo Bd. of Educ., 368 F. Supp. 143, 181-82 (W.D. Mich. 1973), aff'd sub nom. Oliver v. Michigan State Bd. of Educ., 508 F.2d 178 (6th Cir. 1974), cert. denied, 421 U.S. 963 (1975). Until the Supreme Court declared such covenants unconstitutional in 1948, Shelley v. Kracmer, 334 U.S. 1 (1948), they were very common in cities. See U.S. Comm'N on Crvil RIGHTS, supra note 51, at 3 (use of covenants "widespread" after 1917). In some cities racial covenants were still recorded in deeds in the 1970's. See Evans v. Buchanan, 393 F. Supp. 428, 434 (D. Del.) (three-judge court) (Ezans II) (unconstitutional racially restrictive covenants recorded in New Castle County real estate deeds until 1973), aff'd per curiam, 423 U.S. 963 (1975).

91. See, e.g., Liddell v. Board of Educ., 469 F. Supp. 1304, 1324 (E.D. Mo. 1979) (refusal of FHA to insure mortgages prevented black movement into suburbs), rev'd sub nom. Adams v. United States, 620 F.2d 1277 (8th Cir.), cert. dentied, 449 U.S. 826 (1980); Reed v. Rhodes, 422 F. Supp. 708, 788 (N.D. Ohio 1976) (Reed I) (FHA recommended use of racial covenants two years after they were declared unconstitutional in 1948); Bradley v. Milliken, 338 F. Supp. 582, 587 (E.D. Mich. 1971) (noting continuing effects of FHA and VA open advocacy of maintenance of racially harmonious neighborhoods in Detroit), aff'd, 484 F.2d 215 (6th Cir. 1973), rev'd, 418 U.S. 717 (1974).

92. See J. Kushiner, APARTHeid in AMERICA 30-44 (1980) (brief, well-documented account of discriminatory impact of FHA and VA policies); Foley, Institutional and Contextual Factors Affecting the Housing Choices of Minority Residents, in SegRegation in Residential AReas 85, 118-22 (A. Hawley \& V. Rock eds. 1973) (same).

93. See Reed I, 422 F. Supp. at 788 (FHA manual "contained a blatantly separationist policy"); Evans v. Buchanan, 393 F. Supp. 428, 434 (D. Del.) (three-judge court) (Evans II) (manual in use until 1949 advocated racially homogenous neighborhoods), aff'd per curiam, 423 U.S. 963 (1975); Oliver v. Kalamazoo Bd. of Educ., 368 F. Supp. 143, 182-83 (W.D. Mich. 1973) (FHA manual in use until 1950's discouraged introduction of "inharmonious racial groups" into communities and advised that neighborhoods would prove far less stable and desirable if children are compelled to attend school where majority or "goodly number" of pupils "represent a far lower level of society, or an incompatible racial element"), aff'd sub nom. Oliver v. Michigan State Bd. of Educ., 508 F.2d 178 
quently failed, and still do fail, to use their licensing powers against realtors who discriminate. ${ }^{94}$

Although they are not arms of the state, federal agencies can be joined as defendants along with state agencies or ordered to participate in remedies on grounds of privity. ${ }^{95}$ The nature of HUD's involvement in local housing projects makes privity easy to demonstrate. ${ }^{96}$

Some other forms of state action have not influenced school desegregation decisions, so far as the published opinions reveal. These include practices of agencies not directly responsible for housing. For example, explicitly racial zoning ordinances have been unconstitutional since $1917,{ }^{97}$ but remained on the books in many places until the 1950 's. ${ }^{98}$ Siting decisions for highways and other public works projects have also often promoted racial concentration or served to demarcate racial areas. ${ }^{99}$

(6th Gir. 1974), cert. denied, 421 U.S. 963 (1975).

94. See J. KushneR, supra note 92, at 52-56; U.S. COMm'N ON Civil Rights, supra note 64, at 25. In Delaware, the court found that the state not only sanctioned discrimination practiced by the real estate industry but published a primer for realtors which until 1970 included in its Code of Ethics a provision adopted from the code of a realtors' national organization counseling that a realtor "should never be instrumental in introducing into a neighborhood ... members of any race or nationality ... whose presence will clearly be detrimental to property values ...." Evans v. Buchanan, 393 F. Supp. 428, 434 (D. Del.) (three-judge court) (Evans II), aff'd per curiam, 423 U.S. 963 (1975). In the Kalamazoo case, the trial court similarly noted that the State of Michigan not only failed to use its licensing power against realtors who promoted segregation but made preservation of segregation an ethical obligation of realtors, at least until 1948, through the Code of Ethics published by the State Department of Real Estate. Oliver v. Kalamazoo Bd. of Educ., 368 F. Supp. 143, 183 (W.D. Mich. 1973), aff'd sub nom. Oliver v. Michigan State Bd. of Educ,, 508 F.2d 178 (6th Cir. 1974), cert. denied, 421 U.S. 963 (1975); see also United States v. American Inst. of Real Estate Appraisers, 442 F. Supp. 1072 (N.D. Ill. 1977) (realtors' organization interfered with enjoyment of rights guaranteed by the Fair Housing Act by promulgating standards that would cause appraisers to treat race and national origin as negative factors in determining value of dwellings and soundness of home loans).

95. See, e.g., School Dist. v. Missouri, 460 F. Supp. 421, 444 (W.D. Mo. 1978) (Kansas City) (granting school children standing to sue HUD, Department of Health, Education and Welfare, and Department of Transportation on equal protection claims although children did not themselves receive housing or highway benefits), appeal dismissed, 592 F.2d 493 (8th Cir. 1979); Hart v. Community School Bd., 383 F. Supp. 699, 753 (E.D.N.Y. 1974) (HUD participation necessary for effective im-. plementation of court's decree so HUD is "in privity" with city defendants), appeal dismissed, 497 F.2d 1027 (2d Cir. 1974), aff'd, 512 F.2d 37 (2d Cir. 1975).

96. HUD normally cooperates with state agencies in funding and making decisions about siting and constructing public housing. In the Fair Housing Act of 1968 (Title VIII), 42 U.S.C. $\S \S 3601$, 3610 (1976), Congress placed on HUD not merely a duty to respond to complaints of discrimination in federally aided housing, but an affirmative duty to achieve fair housing goals.

97. Buchanan v. Warley, 245 U.S. 60, 80-82 (1917).

98. See U.S. Comm'N ON CiviL RighTs, supra note 48, at 3 (attempts to enforce such ordinances in the courts continued through 1950's).

99. See Sloane, supra note 2, at 85-86. Claims that highway siting decisions promoted residential segregation are part of the ongoing Kansas City litigation. See supra note 21 (discussing status of case); see also supra note 15 (lower court's findings of segregative effect of various state agency decisions in Swann v. Charlotte-Mecklenburg Bd. of Educ., 402 U.S. 1 (1971)); J. KusHNER, supra note 92, at 44-52, 56-63, 86-91 (surveying discriminatory effects of local land use and tax policies). 


\section{Showing Discriminatory Intent}

In 1976 and 1977, the Supreme Court defined strict standards for showing discriminatory intent in equal protection cases. ${ }^{100}$ The impact of these requirements on the housing approach was soon tested: The Indianapolis school desegregation case was one of five which the Court vacated and remanded for reconsideration in light of the new standards. ${ }^{101}$ On remand, the district court set aside all of the evidence of housing discrimination except the public housing siting decisions. From the siting decisions alone, however, the court found proof of discriminatory intent in a combination of circumstantial evidence, foreseeability of consequences, and the absence of credible alternative explanations for siting. ${ }^{102}$ Thus, the Indianapolis case has withstood the new tests.

The Supreme Court's refusal to review the Indianapolis decision leaves standing the use of housing discrimination evidence in a school desegregation case, but it also leaves some questions unanswered. Perhaps the refusal only represents the Court's deference to the trial court's findings of fact on the issue of intent. ${ }^{103}$ On the other hand, the Court may be retreating from the strict standards of purposiveness laid down in 1976 and 1977. A recent voting rights case decided under the equal protection clause reconfirmed the value of circumstantial evidence for determination of intent. ${ }^{104}$ The best evidence of leniency in applying the equal protection intent standard to school desegregation cases comes from two 1979 intradistrict school desegregation cases which saw the Court recognize that intent may be embedded in institutional practices and attenuated over time, and that foreseeable discriminatory impact provides evidence of discriminatory intent. ${ }^{105}$ In general, the federal courts have applied the intent

100. See Washington v. Davis, 426 U.S. 229, 238-45 (1976) (invidiousness must ultimately be traced to purposeful discrimination); Village of Arlington Heights v. Metropolitan Hous. Dev. Corp., 429 U.S. 252, 265-68 (1977) (setting out factors to be considered in assessing official motivation). The Court required only that a discriminatory purpose be a motivating, not necessarily the dominant or primary, factor in decisionmaking. Id. at 265-66.

101. The five remanded cases were Dayton I, 433 U.S. 406 (1977), Brennan v. Armstrong, 433 U.S. 672 (1977) (Milwaukee); School Dist. v. United States, 433 U.S. 667 (1977) (Omaha); Board of School Comm'rs v. United States, 429 U.S. 1068 (1977) (Indianapolis); Austin Indep. School Dist. v. United States, 429 U.S. 990 (1976).

102. United States v. Board of School Comm'rs, 456 F. Supp. 183, 189 (S.D. Ind. 1978) (Indianapolis V), aff'd in part, z'acated and remanded in part, 637 F.2d 1101 (7th Cir.), cert. denied, 449 U.S. 838 (1980). Although a dissenter from the Seventh Circuit's affirmance' of this decision argued that it reflected an overly lenient interpretation of the Supreme Court's standards, United States v. Board of School Comm'rs, 637 F.2d at 1118-21 (Tone, J., dissenting), the Supreme Court denied certiorari, 449 U.S. 838 (1980).

103. See Rogers v. Lodge, 102 S. Ct. 3272, 3278 (1982); Pullman-Standard v. Swint, 102 S. Ct. $1781,1789-91$ (1982) (presence of discriminatory intent "pure question of fact" subject to "clearly erroneous" standard of appellate review).

104. See Rogers v. Lodge, 102 S. Ct. at 3278-81 (voting rights case upholding district court finding, absent direct evidence, of discriminatory purpose behind at-large electoral system).

105. Dayton Bd. of Educ. v. Brinkman, 443 U.S. 526, 535-40 (1979) (Dayton II); Columbus Bd. 
requirement leniently in school desegregation cases, perhaps because the courts are relatively more familiar with the complex and oblique strategies used to preserve school segregation. ${ }^{108}$ Thus, it is not surprising that the Indianapolis decision has survived. Although the housing approach requires the fact finder to inquire into the purposes of housing officials, it should logically benefit from any tendency on the part of the courts to conduct that inquiry with due allowances for the subtlety state and local government entities have shown in promoting segregation in schools.

\section{Conclusion}

Interdistrict school desegregation relief should be available whenever a court finds that governmental housing decisions have contributed significantly to metropolitan-wide school segregation. Such a finding should activate an assumption that state agencies act as arms of a single sovereign. Such a finding should also create a presumption that state action has skewed the processes of local educational decisionmaking. Findings of fact in particular cases, along with social science evidence, have eroded the non-responsibility of government rationale that courts have offered for resisting the housing approach to school desegregation relief. Doctrinal obstacles like the "incremental segregative effect" and discriminatory intent requirements no longer appear insuperable. The housing approach still presents problems, but it holds far more promise today than it did in the late 1970's.

-Robert R. Harding

\footnotetext{
of Educ. v. Penick, 443 U.S. 449, 464-65, 467-68 (1979).

106. For the argument that the intent standard should be applied more leniently in school desegregation cases than in other areas of equal protection law, see Sullivan, The Intent Requirement in Desegregation Cases: The Inapplicability of Washington v. Davis, 10 J.L. \& Educ. 325, 329-30 (1981) (effects of school segregation are psychologically debilitating, and states have special responsibilities in area of public education).
} 